\section{Polityka tożsamościowa organizacji gejowsko-lesbijskich w Polsce a polityka "queer"}

Rafał Majka

STRESZCZENIE: Niniejszy referat stanowi próbę krytycznego przyjrzenia się z perspektywy polityki queer oraz filozofii postmodernistycznej wybranym strategiom językowym oraz narzędziom polityczno-społecznym, używanym przez organizacje gejowsko-lesbijskie w Polsce w celu emancypacji kulturowej oraz legitymizacji prawno-społecznej tożsamości "geja" oraz "lesbijki". Autor pokazuje, w jaki sposób poprzez praktyki tożsamościowe "przycięto" odmieńca do konserwatywnych, heteronormatywnych ram tożsamościowych, aby następnie taką "normalną", "oswojoną" na zasadzie liberalnego podmiotu, tj. części większego systemu, włączyć w istniejący porządek społeczno-polityczny państwa. Autor zauważa, że taka wyzwoleńczo-emancypacyjna strategia tożsamościowa może być - paradoksalnie - szkodliwa dla tych narracji tożsamościowych i wzorców seksualności, które nie mieszczą się w ontologicznych ramach liberalnych konstruktów "geja" i "lesbijki". Dalej, autor analizuje retorykę związków partnerskich/małżeństwa dwóch osób tej samej płci w mainstreamowym dyskursie takich organizacji gejowsko-lesbijskich, jak Fundacja Równości, Kampania Przeciw Homofobii, oraz gejowskich i lesbijskich środowisk kulturotwórczych. Autor zwraca uwage na fakt, że idea związku partnerskiego/małżeństwa "geja" z "gejem", "lesbijki" z "lesbijka", którą w przestrzeni publicznej uważa się za obrazoburczą oraz niezwykle postępowa, jest, wświetle polityki queer, idea konserwatywna, bo potwierdza wyjątkowość, priorytetowość heteronormatywnej instytucji małżeństwa, oraz dyskryminująca, bo przejąwszy koncepcję związku dwóch osób mocno przesiąkniętą judeochrześcijańską wizją przeznaczenia/seksualności jednostki ludzkiej, przemilcza, a tym samym wyklucza, społeczną wartość czy systemową przydatność różnych odmiennych relacji międzyludzkich czy koncepcji związku.

Niniejszy referat stanowi próbę krytycznego przyjrzenia się z perspektywy polityki queer wybranym strategiom językowym oraz narzędziom polityczno-społecznym, używanym przez organizacje gejowsko-lesbijskie w Polsce w celu emancypacji kulturowej oraz legitymizacji prawno-społecznej tożsamości 
"geja" oraz "lesbijki"[1]. Analizując wizerunki "gejów" i "lesbijek" wykorzystane w billboardowej kampanii antydyskryminacyjnej "Niech Nas Zobacza", zorganizowanej na przełomie 2002/2003 roku przez Kampanię Przeciw Homofobii, pokażę, w jaki sposób poprzez praktyki tożsamościowe "przycięto" odmieńca do konserwatywnych, heteronormatywnych ram tożsamościowych, aby następnie taką "normalną", "oswojona" na zasadzie liberalnego podmiotu, tj. części większego systemu, włączyć w istniejący porządek społeczno-polityczny państwa[2]. Postaram się tutaj odpowiedzieć na pytanie, w jaki sposób taka wyzwoleńczo-emancypacyjna strategia tożsamościowa może być - paradoksalnie - szkodliwa dla tych narracji tożsamościowych, wzorców seksualności, które nie mieszczą się w ontologicznych ramach konstruktów "geja" i "lesbijki" zbudowanych na modelu etnicznym/rasowym. Dalej przeanalizuję retorykę związków partnerskich/małżeństwa dwóch, co jest godne zauważenia, osób tej samej płci w mainstreamowym dyskursie takich organizacji gejowsko-lesbijskich jak Fundacja Równości czy Kampania Przeciw Homofobii oraz gejowskich i lesbijskich środowisk kulturotwórczych. Zwrócę uwagę na fakt, że idea związku partnerskiego/małżeństwa "geja" z "gejem" czy "lesbijki" z "lesbijką", uważana w przestrzeni publicznej za obrazoburczą oraz niezwykle postępowa, jest w świetle polityki queer idea konserwatywna, bo potwierdza wyjątkowość, priorytetowość heteronormatywnej instytucji małżeństwa, oraz dyskryminująca, bo przejąwszy koncepcję związu dwóch osób mocno przesiakniętą judeochrześcijańską wizja przeznaczenia/seksualności jednostki ludzkiej, przemilcza, a tym samym wyklucza społeczną wartość czy systemową przydatność różnych odmiennych relacji międzyludzkich czy koncepcji związku.

Polityka tożsamościowa oraz polityka queer pojawiły się w polskiej przestrzeni społeczno-naukowo-kulturowej właściwie w tym samym czasie, po transformacji ustrojowej w 1989 roku, zainspirowane zachodnimi ruchami emancypacyjnymi (polityka tożsamościowa), feminizmem i amerykańskimi studiami gender / queer studies (tutaj polityka queer zwana jest również polityka antytożsamościowa).

Historycznie rzecz ujmując, pierwsza - jako wypracowany system polityczno-społeczny - była polityka tożsamościowa, która rozwinęła się w Stanach Zjednoczonych pod koniec lat sześćdziesiątych. Za impuls, który doprowadził do jej powstania uważa się nalot policji na klub gejowski Stonewall Inn w Nowym Jorku 27 czerwca 1969 roku, w wyniku którego doszło do brutalnego starcia policji z bywalcami/-czyniami klubu. Wydarzenia te spowodowały konsolidację środowiska 
homoseksualnego, które postanowiło rozpocząc walkę o zaprzestanie dyskryminacji osób o orientacji homoseksualnej oraz walkę o równe prawa obywatelskie dla osób o tożsamości "gejowskiej" oraz "lesbijskiej". Działacze/-ki ruchu po Stonewall ukuli/-ły "stabilne" i pozytywne tożsamości "geja" oraz "lesbijki", wymykając się w ten sposób hierarchizującej mocy binarnej opozycji hetero/homo, która, czyniąc praktyki heteroseksualne norma, ustawiała homoseksualizm na z góry przegranej pozycji. Odrzucono zatem etykietkę "homoseksualisty", którą spatologizowały dyskursy medyczny i prawny, a postawiono na pozytywna afirmację swojej kondycji poprzez głoszenie Dumy (tzw. "Gay Pride") z bycia "gejem" oraz "lesbijka". Powołane do życia na zasadzie Althusserowskiej interpelacji, tożsamości "gejowska" i "lesbijska" zostały momentalnie znarratywizowane, czyli, używając języka marksistowskiego historyka Johna D'Emilio, skonstruowano wokół nich mitologię obejmująca mity o "milczeniu, niewidoczności oraz odosobnieniu jako nieodłącznych cechach gejowskiej egzystencji w przeszłości, jak i obecnie"[3] oraz mit "odwiecznego homoseksualisty", według którego "geje i lesbijki zawsze byli/-ły oraz zawsze będa"[4]. Wyznacznikiem tej wynalezionej tożsamości stał się pociag psychoseksualny do osób tej samej płci. Nagle okazało się, że "geje" i "lesbijki" jako osoby o orientacji homoseksualnej istnieli/-ały od zawsze. Chociaż o żadnej orientacji homoseksualnej nie mogło być mowy przed drugą połową XIX wieku. Wówczas dopiero skonstruowano dyskurs (homo/hetero)seksualności jako kulturowy mechanizm regulacyjny, a konstrukty tożsamościowe "geja" czy "lesbijki", jak twierdzi D'Emilio, stały się możliwe do zrealizowania dopiero pod koniec XIX wieku za sprawą kapitalizmu, który doprowadził do erozji rodziny jako podstawowej jednostki produkcji oraz mechanizmu nadzorującego relacje międzyludzkie[5]. Dało to jednostce (zwykle męskiej) możliwość samorealizacji. Przykładem takiej narracji transhistorycznego "gejowstwa" czy "lesbijstwa" jest książka Johna Boswella Chrześcijaństwo, tolerancja społeczna ihomoseksualność: geje ilesbijki wEuropie Zachodniej od początku ery chrześcijańskiej do XIV wieku, w której śledzi on sytuację "gejów" i "lesbijek" od zarania chrześcijaństwa aż do XIV wieku n.e.[6] Co pokazuje nam już dyskursywne działanie reżimu regulacyjnego tożsamości "gejowskiej" i "lesbijskiej", które, by wsunąć się do przestrzeni społeczno-politycznej jako jeszcze jedna dyskryminowana mniejszość i walczyć (podobnie jak wcześniej kobiety oraz Czarni) o należne w świetle praw człowieka swobody i prawa obywatelskie, a przy tym być społecznie wiarygodne, wynalazło swoja historię kulturowa. Pociag oraz praktyki homoseksualne zostały natychmiast "zbiologizowane" przez zaprzęgnięty do pomocy dyskurs medyczny, tworząc "orientację seksualną" jako coś wrodzonego i niezmazywalnego. 
Tak powstała polityka tożsamościowa oparta na modelu esencjalistyczno-etnicznym. Tak zwaną "esencję" stanowił wspomniany pociag psychoseksualny do osób tej samej płci, a "etniczność" rozumiana jest tutaj jako poczucie wspólnoty, w tym wypadku wspólnoty doświadczenia dyskryminacji.

Jednakże działania mające przecież na celu przełamanie kulturowo-społecznej opresji odmienności seksualnej, doprowadziły paradoksalnie do uformowania się hermetycznego "gejowskiego" normatywu tożsamościowego, który zaczał wykluczać wszelką nie(homo)normatywna działalność tożsamościową/seksualna. Okazało się, że licencję na bycie "gejem" posiada osoba, która nie tylko praktykuje seks wyłącznie z osobami tej samej płci, ale jest białym mężczyzną z klasy średniej. W reakcji na esencjalistyczno-etniczny model tożsamości powstała polityka społeczno-kulturowa, którą na początku lat dziewięćdziesiątych nazwano polityką queer. Opierając się na postmodernistycznej krytyce koncepcji tożsamości jako produktu Foucaultowskiego aparatu wiedzy/władzy, produktu, który z góry zawsze będzie wykluczający i niestabilny, bo dialektyczny[7], queer zajał pozycję antyesencjalistyczna, kładąc nacisk na odmienność/różnicę, biorąc pod swoje skrzydła "różne mniejszości, które były wykluczane w ramach wcześniejszych kultur gejowsko-lesbijskich"[8]. Według teoretyczki queer, Judith Butler, "kategorie tożsamości mają tendencje do bycia narzędziami regulacyjnych reżimów zarówno jako normalizujące kategorie opresyjnych struktur, jak też kolektywne punkty wyzwoleńczej kontestacji samej tej opresji"[9], stąd krytyczne stanowisko queer względem kwestii "zbiologizowanej" tożsamości, której hołduje polityka tożsamościowa, oraz postulat relacyjności, sytuacyjności, kontekstualności, temporalności oraz przygodności tożsamościowej.

Polityka tożsamościowa korzystając z modelu tożsamości etnicznej/rasowej, tworzy pewne "stabilne", normatywne tożsamości "geja" i "lesbijki", które następnie na zasadach liberalnych podmiotów stara się "zalegalizować", "znaturalizować" w dyskursach prawno-społecznych dominującego systemu. Sa to więc praktyki emancypacyjno-normalizujące, bardziej zainteresowane "rozpychaniem" już utworzonej przestrzeni polityczno-społecznej w celu włączenia do mainstreamu grup wykluczanych - "gejów" i "lesbijek". Przy czym tożsamość "geja" i "lesbijki" musi najpierw zostać "przystrzyżona" do pewnych normatywnych wymiarów, aby system wogóle ja rozpoznał i zaakceptował jako podmiot, z którym można dyskutować i rozważać jego legitymizację w przestrzeni społeczno-publicznej państwa, utkanej przez 
dominujące dyskursy. Z kolei polityka queer ma na celu właśnie radykalna transformację polityczno-społeczno-kulturowa, obalenie hegemonii heteronormatywnego, fallogocentrycznego, patriarchalnego systemu w kulturze Zachodniej; stąd queer dąży raczej do podważenia całego normatywnego systemu, zdekonstruowania jego części, niż do włączenia się w ten system na jego normatywnych zasadach. Dlatego głównym zadaniem polityki queer, jak powtarza za Rosemary Hennessey Annamarie Jagose, jest denaturalizacja kategorii seksualnych; "poddawanie w watpliwość wszelkiego konwencjonalnego rozumienia tożsamości seksualnej poprzez dekonstrukcję kategorii, [ich] przeciwieństw oraz równoznaczników"[10]. Przykład takiej narracji queerowej prezentuje Frank Browning w swojej książce $A$ Queer Geography: Journeys Toward a Sexual Self, w rozdziale pt. "Do Gays Exist?", w postaci dwudziestosiedmioletniego Daniela, "którego pragnienia", jak pisze Browning, "odchylały się od przyjętego mainstreamu "[11]. "Wolność, którą odczuwał, nie była związana z faktem, że zamieszkiwał jakąś nowa, zdefiniowana tożsamość, lecz wynikała z faktu, że wymykał się wszystkim tym, którzy chcieliby narzucić mu jakąkolwiek prostą społeczną lub psychologiczną tożsamość"[12]. Zatem, żeby spełniać swoją kontestatorską rolę, termin "queer", podaje za Butler Joanna Mizielińska, "ma pozostać otwarty, przekraczający jakiekolwiek granice grupowe, odrzucający sztywne seksualne kategorie i włączający zarówno gejów ilesbijki, jak też biseksualistów, transseksualistów, transgenderystów, drags, ale też heteroseksualistów, krótko mówiąc, wszystkich buntujących się przeciwko normalizującym zachowaniom, odrzucającym społeczne etykietowanie i hierarchizowanie zachowań seksualnych"[13]. I, jak dodaje Browning, chodzi tutaj o "powiększenie i wzbogacenie seksualnej kultury społeczeństwa", a nie o używanie aparatu wiedzy/władzy do konstruowania hermetycznych tożsamości seksualnych[14].

Wiosna 2003 roku Kampania Przeciw Homofobii przeprowadziła pierwszą w Polsce kampanię społeczna, której celem było przeciwdziałanie homofobii idyskryminacji ze względu na orientację seksualna. Przedsięwzięcie nosiło nazwę "Niech Nas Zobacza" i miało formę trzydziestu fotografii przedstawiających pary "gejów" i "lesbijek" trzymające się za ręce. Fotografie miały być pokazywane w prestiżowych galeriach dużych miast, część miała zostać zaprezentowana na billboardach. Organizatorzy opisywali koncept kampanii w następujący sposób:

"Wszystkie zdjęcia cechuje ta sam linia artystyczna: pokazane są sylwetki osób na tle zimowej miejskiej scenerii, pary trzymają się za ręce i patrzą prosto w obiektyw aparatu. Barwy są stonowane i spokojne. Ludzie na nich uwiecznieni budzą sympatię. 
W zamyśle autorki zdjęć, Karoliny Breguły, fotografie miały być podobne do siebie, wręcz monotonne, po to, aby widz, który obejrzy wszystkie 30 zdjęć, znudził się nimi i pomyślał, że mija na ulicy codziennie setki takich ludzi, - że geje ilesbijki to nie żadna sensacja. Jeśli homoseksualiści wyglądają tak normalnie i przeciętnie, są właśnie tak samo normalni jak on, widz.[15]"

Kampania generalnie wywołała wrzawę. Niektórzy działacze gejowscy, jak Paweł Leszkowicz, nazwali ja nawet polskim "Stonewall"[16]. Pod względem użytych strategii politycznych była ona jednak działaniem wysoce asymilacjonistycznym i "normalizującym" tożsamość "gejowska" i "lesbijska". Ciężko jest też nazwać "podmiotowościa gejowska" czy "podmiotowościa lesbijska" to, co próbowano przepchnąć jako właśnie taką "podmiotowość" do przestrzeni społecznej, gdyż nawet w samym ruchu gejowsko-lesbijskim nie istnieje jedna, prawdziwa "podmiotowość". Oczywiście podążając szlakami przetartymi przez amerykańskie ruchy wyzwolenia "gejów" i "lesbijek", starano się uświadomić społeczeństwu, że jedyną rzeczą odróżniająca "gejów" i "lesbijki" od "(hetero)społeczeństwa" jest fakt, że kochaja oni/-e osoby tej samej płci. Pewnie nie bez znaczenia był fakt, że jednopłciowe pary trzymały się za ręce. To symboliczny gest zażyłości, bliskości emocjonalnej, który wydawał się w zamiarze wyrażać normatywną koncepcję związku, który jest do zaakceptowania pod względem etycznym, bo opiera się na uczuciu, a nie na czystym pożądaniu i nie jest jedynie wymiana korzyści seksualnych. A etyka w Polsce pozostaje pod silnym wpływem katolicyzmu. Punktem odniesienia stała się zatem polska norma, którą można by określić słowami organizatorów "Niech Nas Zobacza", normą "stonowana", "spokojną", "monotonna", "przeciętna" oraz "monogamiczna". "Gej" i "lesbijka" zostali przedstawieni jako "normalne" osoby żyjące w parach; przy okazji okazało się, że "normalność" w wydaniu polskim to również bycie osobą pełnosprawna, zamożna, mieszczącą się w przedziale wiekowym od dwudziestu do czterdziestu lat, pochodząca z klasy średniej. Sięgając do filozofii marketingu, "(hetero)społeczeństwo" stało się konsumentem, któremu podsunięto produkt w postaci "polskiego geja" i "polskiej lesbijki", pieczołowicie "dopasowany" do konkretnych oczekiwań ontologicznych odbiorcy, "przystrzyżony" do właściwych polskiemu "(hetero)człowiekowi" wymiarów światopoglądowych. Jak ironicznie zauważa Robert Kulpa,

"Chłopcy jak przystało na chłopców - zwyczajni, w dżinsach, nie przegięci, normalni. Dziewczęta - zwyczajne, w spodniach i spódnicach, dziewczęce, żadnych męskich lesb. Wszystko takie cacy i normalne, zwyczajne, że aż szlag człowieka trafia. Ruch queer w takich momentach pyta się: a gdzie są travesti? Gdzie 
przegięci faceci? Gdzie są butch ? Czyżby nie istniały? Czyżby nie było wśród lesbijek i gejów punków, anarchofeministek, fanów skóry i hipermaskulinistycznych facetów w układach S/M? Dlaczego nie zostali pokazani w tej akcji? Czyżby dlatego, że nie pasuja do lansowanego wzorca "normalnej lesbijski", "normalnego geja"? Czyżby byli zbyt "kontrowersyjni" dla dopiero co przebłaganego społeczeństwa, i nie można ich pokazywać w prasie itelewizji, "bo ludzie znowu powiedza, że to zboczeńcy"?[17]"

Pojawia się tutaj problem. Tożsamość "gejowska" i "lesbijska", którą zaprezentowano w kampanii "Niech nas zobacza" jest tożsamością wysoce z(hetero)normatywizowana, czyli taka, która naśladuje, reprodukuje, duplikuje normatywną tożsamość systemową - tożsamość regulowaną przez dominujące w polskiej przestrzeni społeczno-kulturowej ideologie heteronormatywności, katolicyzmu, konserwatyzmu światopoglądowego oraz patriarchatu. Zamiast celebrować odmienność, podkreślać funkcjonalność różnic oraz wartość bogatego doświadczenia emocjonalno-seksualnego i tożsamościowego, Kampania Przeciw Homofobii postawiła na bycie "tożsamym" z "tożsamością heteroseksualna", dla której homoseksualność jest przecież już zawsze Kristevowskim "abjektem"[18]. KPH widocznie uznała, że tylko wtedy polski system rozpozna "geja" i "lesbijkę" jako interlokutorów, kiedy zostana oni podciagnięci/-te do "normy" - wymodelowani/-e strategicznie do pewnej normatywnej tożsamości. Taka polityka może świadczyć o stopniu, wjakim hegemoniczne dyskursy zdominowały polską przestrzeń społeczna, skoro nawet sam "gej" czy "lesbijka" nie są w stanie w Polsce wyjść poza pewna ("obowiązkowa") kolektywna, monolityczną tożsamość seksualną. Jednostki, obojętnie czy hetero, czy homo (nie wspominając już o innych odcieniach seksualnych), muszą spełnić cały szereg jednakowych wymagań kulturowych, aby można je było zaakceptować jako liberalny podmiot w przestrzeni społeczno-politycznej. Jest to niepokojące, gdyż sugeruje głęboką "niedemokratyczność" systemu w sensie społeczno-kulturowym. "Niedemokratyczność" rozumiem tutaj jako brak przyzwolenia na obecność odmienności nienormatywnych praktyk tożsamościowych. Jest to brak zgody na przestrzeń, w której każda narracja tożsamościowa jest w stanie bez przeszkód systemowych i społeczno-kulturowych realizować swój pomysł na "dobre życie", żyć w zgodzie ze swoimi wartościami. Owa "niedemokratyczna" logika ujawnia się w systemowym (przymusowym) obowiąku każdej praktyki tożsamościowej do wpasowania się w "normę", co z kolei powoduje utratę specyfiki stylu życia, modyfikację wartości i zasad (bo trzeba się "dopasować"). Tak daleko posunięte procesy homogenizacji 
i normatywizacji są praktykami przemocy kulturowej, ponieważ sankcjonując jeden szablon, nie dają jednostce możliwości wyboru spośród różnych pomysłów na życie, czy różnego rodzaju relacji i związków międzyludzkich, już z góry, dyskursywnie, tworząc tylko jeden "wybór" - normę. Co gorsza, przycinając reprezentacje polityczne nienormatywnych praktyk seksualnych do tej normy, sprawiaja, że odmienne doświadczenia tożsamościowe poddawane sa - w rozumieniu Deleuze`a i Guattariego - procesowi "nadkodowania"[19].

Kolejna sprawa: czy jeśli uda się "oswoić" społeczeństwo z taką niezdrowo "normalna" sylwetką "geja" i "lesbijki", to czy swoja kampanię mają rozpoczać "geje przegięci" i "męskie lesbijki", osoby uprawiajace praktyki S/M, wszystkie inne odcienie "gejowstwa", "lesbijstwa", które nie mieszczą się w koncepcji na "geja" lub na "lesbijkę" z "Niech Nas Zobacza" - a co z biseksualistami, co z osobami transgenderowymi, transseksualnymi, interseksualnymi, co z osobami queer ? Czy mają one tworzyć własne ruchy wyzwoleńcze i dopasowywać się do społeczeństwa? Czy kiedy osoby transseksualne będa starały się o "adopcję społeczną", to zostana poparte przez "normalnych gejów" i "normalne lesbijki"? Czy może "normalni" będą bali się wypaść z łask społecznego hegemona, jakim jest heteronormatywne, konserwatywne społeczeństwo? Czy każdy "dysydent seksualny"[20], używając terminu Jonathana Dollimore'a, będzie musiała uprawiać politykę tożsamościowa, by się odpowiednio wkomponować? A może to właśnie społeczeństwo powinno dopasować się do Innego?

Nie chodzi tutaj o zanegowanie przydatności polityki tożsamościowej, jej wartości i siły emancypacyjnej, czy o nawoływanie do całkowitego porzucenia praktyk tożsamościowych bądź polityki reprezentacji, co raczej o Butlerowską "krytyczną genealogię" tychże praktyk. O krytyczne zastanowienie się nad (ludzkimi) kosztami takiej polityki. Bo jak Butler zapytuje, "jaki sens ma zyskiwanie reprezentacji przez podmioty skonstruowane w drodze wykluczenia tych, którzy/które nie spełniają niewypowiedzianych normatywnych warunków bycia podmiotem?"[21] Polityka tożsamościowa jest reakcją na pewną określona materialna rzeczywistość systemu, na działanie konkretnej machiny państwa, państwa, które jest tutaj i teraz . A jest to państwo, które przemilcza, wyklucza, dyskryminuje nieheteroseksualne praktyki tożsamościowe, życiowe, jakimi są (według $\mathrm{KPH}$, tylko) "gejowstwo" i "lesbijstwo". Polityka tożsamościowa obliczona jest na pewne konkretne cele społeczno-polityczne; bardzo mocno zatem zasadza się $w$ istniejących warunkach materialnych danego państwa/systemu. "Pragmatycznie" rzecz biorąc (tzn. 
sugerując się polityczno-społeczną kalkulacją w stylu: Co będzie łatwiej i szybciej "przepchnać" - pare gejów czy może transseksualist(k)ę lub lesbijską komunę?), polityka tożsamościowa wydaje się polityką bardzo przydatna i wartościowa, ponieważ walczy ona o życie (w sensie rozpoznania przez system) dyskryminowanych, krzywdzonych i opresjonowanych projektów tożsamościowych "geja" i "lesbijki", o wyzwolenie tej grupy społecznej spod systemowego jarzma "obowiązkowego heteroseksualizmu". Walcząc jednak o uwolnienie "geja" i "lesbijki" spod dyktatu heteroseksualizmu, polityka tożsamościowa już jednak nie stara się uwolnić ich od katolicko pojmowanej heteronormatywności; pewnego forsowanego przez hegemoniczne dyskursy zestawu "oczekiwanych" społecznie i kulturowo cech, zachowań, póz, stylu życia jednostek. Co uprawiający/-e taką politykę mogą tłumaczyć w ten sposób, że polityka tożsamościowa bierze pod uwagę to, na jakim poziomie "akceptacji", "zrozumienia", "szacunku" względem odmienności jest społeczeństwo polskie. I jeszcze argumentować tym, że "łatwiej" i "szybciej" zaistnieć odmienności w przestrzeni publiczno-społecznej, jeśli odwoła się liberalnie do wspólnego, uniwersalnego, "doświadczenia człowieczego"; jeśli będzie ona budować swą politykę i "podmiotowość" na bazie dominujących ideologii, hegemonicznych dyskursów, zamiast ustawić się na kontrze do istniejącego systemu. Jednakże z perspektywy queer jest to już zawsze odtwarzanie systemowej machiny opresji, popadanie w schematy wykluczania.

Kolejną kwestia, która spędza sen z powiek wielu organizacjom i grupom gejowsko-lesbijskim jest kwestia zawierania małżeństw przez osoby tej samej płci. Czy raczej kwestia wchodzenia przez osoby tej samej płci w "związki partnerskie" (jak to zostało polityczno-prawnie nazwane w Polsce z uwagi na fakt, że polska konstytucja jednoznacznie definiuje "małżeństwo" jako związek "kobiety" i "mężczyzny").

Według "logiki" liberalnego dyskursu praw człowieka, "gejom" i "lesbijkom", jako mniejszości seksualnej, należą się takie same prawa obywatelskie, jakimi cieszy się heteroseksualna, czy raczej (ideologicznie) "uheteroseksualniona", część społeczeństwa. W świetle asymilacjonistycznej polityki tożsamościowej społeczne przyznanie parom jednopłciowym możliwości zawierania małżeństw, czy raczej wchodzenia w związki partnerskie, oraz prawne rozpoznanie takich zwiazków przez państwo dałyby "gejom" i "lesbijkom" pewien "pakiet praw", który na zasadach prawdziwie demokratycznych postawiłby znak równości między instytucjami heteromałżeństwa i homomałżeństwa, co z kolei doprowadziłoby do zmiany statusu społeczno-politycznego "gejów" i "lesbijek". Od "bezpłodnego" 
społecznie produktu ubocznego państwa, "gej" i "lesbijka" awansowaliby, w sensie ontologii politycznej, do rangi członka wspólnoty państwowej, który jest "cenny", "ma znaczenie", jest "tak samo ważny" właśnie poprzez fakt prawno-społecznego uczestnictwa w machinie (re)produkcyjnej państwa. Czyli między innymi poprzez zakładanie rodziny, adopcję i wychowywanie dzieci przez pary jednopłciowe, z naciskiem na słowo "pary", czyli szereg heteronormatywnych wzorców, rytuałów społecznych, które "para" jednopłciowa zobowiązuje się imitować/odtwarzać. Polityka tożsamościowa dąży więc do przebudowania społeczno-prawnej przestrzeni heteronormatywnej kultury, cele swe upatrując w zaanektowaniu i rozciagnięciu na pary jednopłciowe szeregu opcji prawno-społeczno-kulturowych, które są integralną częścią obowiązkowej (hetero)narracji "rozrodczego futuryzmu"[22], używając terminu Lee Edelmana.

Jednak polityka tożsamościowa KPH, Fundacji Równości czy lewicowych ruchów homofilnych, nie tylko chciałaby odtwarzania praktyk heteronormatywnych przez "gejów" i "lesbijki", ale również zgadza się na etykę proweniencji judeochrześcijańskiej, obecna w sferach publicznej ispołeczno-kulturowej. Zarówno w projekcie ustawy o rejestrowanych związkach partnerskich autorstwa prof. Marii Szyszkowskiej z 2004 roku czy w propozycji podobnej ustawy autorstwa redaktora naczelnego portalu gejowsko-lesbijskiego gaylife.pl, Jacka Adlera, w manifeście założycielskim Fundacji Równości, czy w dyskursie KPH, związek partnerski "gejowski" czy "lesbijski" definiowany jest jako związek "dwóch osób", "pary", jako twór monogamiczny, czyli wierna kopia heteronormatywnej instytucji małżeństwa. Taka definicyjna "monogamizacja" związku gejowskiego czy lesbijskiego wypływa między innymi stąd, że organizacje gejowsko-lesbijskie starają się obalić pewne tkwiące wświadomości normatywnego, katolickiego społeczeństwa stereotypy[23]. Kieruja się przy tym pragmatyką polityczno-społeczna, która upatruje w liberalnym stanowisku, z dyskursem praw człowieka jako orężem, sposobu na w miare szybkie "załatwienie" nieheteroseksualnej opcji statusu "podmiotu" w przestrzeni społeczno-polityczno-prawnej. Jest to jednak ciagle tylko praktyka przypominająca "załatwianie" sobie "pracy" w firmie, do etykiety, przepisów, zasad której musimy się dostosować.

Robert Biedroń w swoim Tęczowym elementarzu pisze, że "zawarcie małżeństwa jest symbolem i wyrazem najgłębszej więzi między dorosłymi ludźmi. Warto więc, by było ono dostępne również dla par homoseksualnych, które tworzą związki oparte na tak samo głębokiej więzi jak osoby heteroseksualne"[24]. Jest to nie tylko brutalne przycięcie do heteronormatywnych, katolickich, w przypadku Polski, wymiarów różnorodnej, niekonwencjonalnej 
kultury seksualnej środowiska gejowsko-lesbijskiego i środowiska odmieńców, ale również ukłon w stronę założenia o wyjątkowości, świętości instytucji małżeństwa, jak i potwierdzenie jej centralnego znaczenia worganizacji sfery społeczno-kulturowej. Ten jeden gest retoryczny wykluczył, zlekceważył szereg innych konfiguracji i praktyk seksualno-emocjonalnych, które przecież dla wielu osób moga również być "symbolem i wyrazem najgłębszej więzi między dorosłymi ludźmi". Jeden z teoretyków queer, Michael Warner, jednoznacznie stwierdza, że

"'"małżeństwo dyskryminuje (...) [,bo] (...) uświęca jedne pary kosztem innych. (...) Dla pary, która się pobiera, małżeństwo wydaje się czymś nobilitującym (...). Jedno spojrzenie z boku i widzi się założenie: nie jesteś zamężny, zamężna, żonata, żonaty, ty i twoje relacje są mniej warte. Bez takiego efektu instytucja małżeństwa nie byłaby w stanie napełnić czyjegoś życia znaczeniem. Nobilitacja i poniżenie muszą iść w parze. Małżeństwo robi jedno kosztem drugiego (...)".[25]"

Prawno-społeczna instytucja małżeństwa jest kluczowym mechanizmem nadzoru i regulacji intymnego, prywatnego życia obywateli przez (hetero)państwo, które działa w imię "rozrodczego futuryzmu". Jest to rodzaj inżynierii społecznej, która, jak pisze Warner, za pomoca aparatu administracji państwowej "wywiera wpływ na sferę przyjemności oraz relacji intymnych, dążąc do stłumienia różnorodności sposobów życia, upoważniając państwo do uprzywilejowania jednej - $i$ tak już normatywnej - formy życia"[26]. Instytucja ta obdarowuje obywateli sporym pakietem praw, uprawnień, przywilejów i zaszczytów, do których należą szacunek i akceptacja społeczna, "manipulując w ten sposób nie tylko ekonomicznymi wyborami obywateli/-ek, ale także ich konkretną inormatywną wizją właściwego życia"[27]. Z perspektywy demokratyczności, rozumianej jako prawo każdego członka oraz każdej członkini wspólnoty państwowej do wyboru takiego sposobu życia, jaki jemu czy jej odpowiada, tak namacalna i agresywna ingerencja państwa w praktykę życiowa oraz - poprzez całość procesów i mechanizmów społeczno-kulturowo-politycznych - dyskursywnie wich wybory i przekonania na temat związków, relacji oraz wartości z nimi zwiazanych, jest więc czymś fundamentalnie niedemokratycznym.

Instytucja małżeństwa powołuje do życia i legitymizuje pewna "święta" sferę prywatności obejmującą seksualność i praktyki seksualne małżonków, dyscyplinuje jednocześnie na wiele różnych nieprzyjemnych sposobów jednostki znajdujące się na zewnątrz. Poza małżeństwem bowiem seksualność i praktyki 
seksualne podlegaja ścisłemu nadzorowi, surowej kontroli nie tylko w sensie administracyjno-prawnym (przykład prostytucji), ale również w sensie społeczno-kulturowym (stosunek do poligamii, promiskuityzmu czy komuny seksualnej). W dyskursie publicznym małżeństwo wiązane jest z dojrzałościa, jest wyrazem odpowiedzialności dwojga osób, aktem dojrzałej miłości, co sprawia, że wszystkie inne sposoby życia lub bycia z druga osoba, lub z innymi osobami, muszą wydawać się niepoważne, niedojrzałe, nierokujące na przyszłość i nieopłacalne (bo nie uzyskuja szeroko rozumianego wsparcia, dofinansowania, przywilejów czy statusu prawnego od państwa). Co więcej, znaczny udział oraz olbrzymi wpływ Kościoła katolickiego na rzeczywistość Polski w trakcie i po transformacji ustrojowej przyniosły hegemonię etyki katolickiej w sferze kulturowo-społeczno-politycznej, która uwidacznia się w decyzjach, działaniach administracyjno-politycznych, polityce społecznej i zdrowotnej czy podejściu państwa polskiego do takich kwestii, jak pornografia, domy publiczne, prostytucja, wolna miłość, praktyki homoseksualne czy biseksualne, życie w konkubinacie. Które to kwestie, jedne w mniejszym, inne w większym stopniu, uważane są za życie "w grzechu", naznaczone piętnem wstydu i traktowane jako aberracje moralne. Jednostki od urodzenia socjalizowane sa do wchodzenia w związek małżeński, musztrowane (kulturowo) dyrektywnymi aktami mowy w stylu "Jak będziesz duży, będziesz miał żonę" czy "Jak będziesz duża, wyjdziesz za mąż", albo "Będę bawiła twoje dzieci" itp., warunkowane przez dominujące reprezentacje monogamii, heteronormy i patriarchatu. W mainstreamowej przestrzeni publiczno-społecznej, podszytej etyką katolicka, instytucje rodziny i małżeństwa funkcjonuja jako ściśle ze soba powiazzane, ustawiając teleologicznie wizję życia jednostki w społeczeństwie.

Bardzo niebezpieczny jest również liberalny dyskurs dotyczący prywatności, który to, pod pozorem troszczenia się o równe prawa dla wszystkich tych tożsamości, które funkcjonuja w społeczeństwie jako liberalne podmioty, tak naprawdę podtrzymuje status quo dominującej konfiguracji dyskursywnej przestrzeni społecznej. Postuluje on bowiem rozdział na sfere prywatną i publiczną. W sferze prywatnej pozwala się jednostkom być i żyć według swoich własnych wzorów tożsamościowych (ale niestety tylko takich, które system rozpoznaje jako liberalny podmiot) jako "geje" czy "lesbijki", natomiast w sferze publicznej, która jest fałszywie definiowana jako "neutralna", oczekuje się od jednostek wejścia w rolę "neutralnego" (pod względem orientacji seksualnej czy płci), "uniwersalnego" obywatela. Jest to więc przyzwolenie na akceptowana przez system odmienność jednostki prywatnie, ale publicznie już oczekuje się od niej 
"szablonowości", dopasowania się do określonego schematu "obywatela", do pewnej normy. Liberalny dyskurs prywatności stanowi więc nie tylko doskonałe narzędzie egzekwujące normę, ale także maskuje dominację ideologiczną heteronormatywności, androcentryzmu czy konserwatyzmu obyczajowego. Co więcej, trzymając nienormatywną (np. seksualnie) jednostkę w złudzeniu "wolności" w prywatnym życiu, celuje w jej mechanizmy stawiania oporu i walki o "wyzwolenie", "wolność", bo jak mógłby argumentować liberalny "gej", skoro wolno mi żyć prywatnie życiem "geja", to jednak świadczy to o tym, że państwo troszczy się o moja odmienność, o moje "równe prawa"; to nic, że muszę dopasować się publicznie do pewnego uniwersalnego kodu tożsamościowego, jest to poświęcenie, na które decyduja się wszyscy wimię pokojowej koegzystencji i "neutralności obyczajowej" państwa. Jednak jakby przyjrzeć się krytycznie przestrzeni publicznej, to na przykładzie osoby, która funkcjonuje na co dzień z obrączką na placu, informująca o tym, że pozostaje ona w monogamicznej instytucji małżeństwa, czy prezydenta, który poprzez pokazywanie się w mediach czy na delegacjach z małżonką podkreśla swą heteroseksualność, widać, że koncept "neutralności" jest tylko ideologiczną maską dla pewnego systemu, który wytworzyły hegemoniczne dyskursy. "Neutralność" bowiem to tak naprawdę systemowa norma, a normą jest m.in. heteroseksualizm, monogamia i instytucja małżeństwa.
Przytoczone przykłady dosyć dosadnie wskazują na iluzję rozróżnienia prywatne/publiczne; skoro z małżeństwa nie da się wydzielić "prywatnego" i "publicznego", to w jaki sposób można "w domu", "w czterech ścianach", zostawić swoją nienormatywna seksualność? Seksualności, tak jak i płci, nie da się odwiesić, nie da się być "w domu po kryjomu" "gejem" czy "lesbijka", a poza tym "normalnym" obywatelem, podporządkowanym ideologicznemu konsensusowi, który wynegocjowały między sobą dominujące ideologie.

Sugeruje to właśnie również fałszywność twierdzenia, że "neutralność" tego, co "publiczne" jest bezideologiczna. Ta liberalna "neutralność" jest jak najbardziej ideologiczna. Ci/te którzy/które uprawiają dyskurs liberalny wydają się uważać, że żyja w jakiejś ideologicznej próżni, niewarunkowani/-e przez żaden dyskurs, niemotywowani/-e żadnymi przesłankami światopoglądowymi. Nie jest jednak tak, że sposób, w jaki jednostka realizuje się w życiu prywatnym, jej zasady, wartości, że to wszystko kształtowane jest przez jej wolę, bez nacisków ideologicznych, ekonomicznych czy kulturowych. Styl życia czy (normatywna) tożsamość, która, jak się jednostce wydaje, wybiera, a tak naprawdę jest do niej od początku socjalizowana, zależą w dużym stopniu od kontekstu historycznego, warunków społeczno-kulturowych i materialnych. Ponadto cały ten system, 
w którym jednostka jest zanurzona i w którym jest "znarratywizowana", a który jest układem dominujących dyskursów w przestrzeni społeczno-kulturowej państwa, ma olbrzymi wpływ ideologiczny na wizję "właściwego życia", "dobrego życia", warunkuje wartościowanie pewnych zjawisk i konstruktów. Zatem obstawanie przy liberalnym podziale prywatne/publiczne, podziale na dwie osobne, nie majace na siebie wpływu, sfery jest - patrzac z perspektywy marksistowskiej błędem, bo (jeśli już posługujemy się pojęciami "prywatne" i "publiczne") to, co uchodzi za "prywatne" jest tak naprawde właśnie konstruowane, motywowane przez to, co uchodzi za "publiczne". Określony dyskursywny system warunkuje życie i tożsamość jednostki, a później jednostka, odtwarzając ten wzorzec "życia" i praktyki normatywnej tożsamości, podtrzymuje i wzmacnia ten system.

Polityka społeczna wcześniej wspomnianych organizacji gejowsko-lesbijskich oraz lewicowych ruchów homofilnych, występując z pozycji liberalnego dyskursu praw człowieka, domaga się dla "gejów" i "lesbijek", jako opcji homoseksualnej, kolejnego z praw wykutych wheteronormatywnym matriksie państwowym: prawa do wchodzenia w związek partnerski wraz z całym pakietem uprawnień i zaszczytów, łącznie z prawem do prywatności i poszanowania domostwa. Oczywiście, jeśli bierze się pod uwagę kalkulację polityczno-społeczna, strategia ta wydaje się być jak najbardziej słuszna i pewnie - w perspektywie długofalowej - efektywna. Pragmatyka społeczno-polityczna sugeruje bowiem, że jednak szybciej uda się "załatwić" sprawę związków partnerskich, aniżeli skłonić szeroko rozumiane państwo do zaakceptowania każdego zwiąku czy relacji, w jakie wchodzą jego obywatele i obywatelki. Podnoszone są również argumenty prawno-społeczne na korzyść (monogamicznego) związku partnerskiego, między innymi: kwestia dziedziczenia, prawo do informacji o stanie zdrowia partnera/-ki czy ulgi podatkowe, które - w świetle liberalnej koncepcji obywatelstwa - jak najbardziej należą się "gejom" i "lesbijkom" jako pełnoprawnym obywatelom i obywatelkom, płacącym podatki, podtrzymującym system poprzez pracę i uczestnictwo w jego strukturach. Kodyfikacja zwiazku partnerskiego z jego "gejowskim" i "lesbijskim" podmiotem, z jednej strony, postawiłoby "gejów" i "lesbijki" w sensie systemowo-prawnym na równi z tożsamościa heteroseksualną, być może inicjując bądź przyśpieszając proces kulturowo-społecznego oswajania się "hetero-społeczeństwa" z odmiennością "gejowska" i "lesbijska"[28]. (Ta "odmienność", jak pokazała kampania "Niech Nas Zobacza", "geja" czy "lesbijki" nie wyszłaby jednak poza pociag psychoseksualny do osoby tej samej płci; poza tym, "gej" i "lesbijka" byliby przedstawiani jako "normalni", "tacy sami jak inni".) Z drugiej strony, taka legalizacja 
prawna, a dalej systemowa, jest "nadkodowaniem" relacji pomiędzy osobami tej samej płci, jej normatywizacja, "przepisaniem" tych relacji w języku dominujących ideologii. Właściwie jest to dyskursywne napisanie, stworzenie zasadnej, optymalnej (czyli "do przyjęcia" przez kato-hetero-system) relacji "gejowskiej" czy "lesbijskiej". Związek partnerski, uprzywilejowany, będzie robił w sumie to samo, co instytucja małżeństwa - będzie warunkował wizję "właściwego", "dobrego" życia, w tym przypadku, "gejowskich" i "lesbijskich" tożsamości seksualnych.

Problemem tutaj jest także system prawny, z założenia mający "uporządkowywać", wymagający klarowności, jednoznaczności. Prawo jest zbiorem norm, a normy są już zawsze konstruowane i działają poprzez wykluczenie. Związek partnerski dwóch "gejów" lub dwóch "lesbijek" w sensie prawno-administracyjnym stanowi "przekopiowanie" instytucji małżeństwa ze wszystkimi jej benefitami; stąd ingerencja na poziomie systemu jest znikoma. Już trudniej wyobrazić sobie sytuację, kiedy porządkiem prawnym trzeba by było objąć, na przykład, komunę "gejowska" lub "biseksualna", trójkąt "lesbijski" czy inną konfigurację odmieńców lub osób "heteroseksualnych". W przypadku, powiedzmy, śmierci jednej z pięciu lesbijek żyjących w komunie seksualno-emocjonalnej, można by się zastanawiać, jak prawo poradziłoby sobie z kwestia spadku. A co, jeśli członkini, na przykład, trójkąta byłaby jednocześnie uczestniczką komuny, pozostając w dwóch rozpoznawanych prawnie związkach, a prawo musiałoby ją właśnie "rozpoznać" i zinterpretować w tej postaci. Z pewnością takie dywagacje można by ciagnąc w nieskończoność. Bo system prawny musiałby ciagle dostosowywać lub tworzyć "normy" prawne dla coraz to nowych konfiguracji, związków, relacji międzyludzkich. Jednak takie prawo przestałoby być "prawem" sensu stricte - bo zamiast tworzyć normy, musiałoby je nieprzerwanie dekonstruować; zamiast być przejrzyste i jasne, byłoby nieustannie nieuporządkowane pojęciowo, byłoby prawem-w-stawaniu-się ; zamiast tworzyć rzeczywistość społeczna, kodyfikując i warunkując jej charakter, zależałoby od twórczego "widzimisię" tej rzeczywistości (od jej nomadycznych, afirmacyjnych, kreatywnych sił), podażając za kultem wieloznaczności i różnorodności. Byłoby to zaprzeczenie prawa w jego obecnej formie. Co sugeruje już marksistowski wniosek, że prawo uzależnione jest całkowicie od warunków materialno-historycznych, w jakich powstaje. Jest produktem określonej konfiguracji sił społecznych i kulturowych; pewnego systemu, który w danym miejscu i czasie się wytworzył. Obecne prawo to skutek systemu zhegemonicznymi dyskursami m.in. heteronormatywności i patriarchatu, "napędzanego" (meta)narracja "rozrodczego futuryzmu". Co więcej, prawo 
stanowi właśnie taki swoisty Foucaultowski dyskursywny mechanizm regulacyjny systemowego status quo. Nie jest więc ono biernym narzędziem systemu, tylko również oddziałuje na niego, podtrzymujac i umacniając go; dyscyplinuje tożsamości i cielesności do oczekiwanych przez ten system zachowań. Dlatego wszelkie próby emancypacyjne, pozostające w obrębie prawnego status quo, będa tak naprawdę praktykami normalizacyjnymi, powtarzającymi mechanizm opresji i wykluczenia.

Dwuznaczne i problematyczne mogą się również wydawać same praktyki emancypacyjne. Dążą one do nadania jakiejś grupie społecznej statusu liberalnego podmiotu i jej legalizacji w sferze publiczno-społecznej, a jednak - jak to widać na przykładzie "Niech Nas Zobaczą" - stwarzana, emancypowana "podmiotowość" jest negocjowana na warunkach systemu, jest ona tym, co byłoby "strawne" w sensie etycznym i estetycznym dla normatywnej, dominującej grupy - w tym wypadku, "(hetero)społeczeństwa". Słowem, akceptowane sa podmioty, które re produkuja normę. Jednakże, podmioty są produkowane, negocjowane dyskursywnie wpolitycznym procesie emancypacji; nie ma żadnego jednego przedemancypacyjnego podmiotu, jest tylko fantazmat, z którego się korzysta i do którego się odwołuje, pragnąc wyswobodzić jakąś praktykę tożsamościową. Ponadto z kwestią emancypacji zwiazana jest również polityka reprezentacji polityczno-społecznej, tak krytykowana przez filozofię postmodernistyczna. Bowiem jak pisze Todd May, "praktyki mówienia ludziom, kim są i czego chca, wznoszą barierę między nimi a tym (lub czym) mogliby/mogłyby się stać"[29]. Co więcej reprezentacja immanentna strukturze państwowej, w szczególności demokracji, tworzy pewne standardy zachowań, normy, a- jak pisze May, posiłkując się Deleuzjańskim odczytaniem Nietzschego, "projekt oceniania życia w odniesieniu do zewnętrznych standardów jest przyzwoleniem na to, aby siły reakcyjne zdominowały siły aktywne; gdzie siły reakcyjne są tym, co 'nie pozwala sile aktywnej być tym, czym ona może się stać'"[30]. Innymi słowy, siła aktywna jest swoistym potencjałem ciagłego stawania się jednostki, potencjałem wymykania się kategoriom, normom, wszelkim "stabilnościom"; jest to nieprzerwane eksperymentowanie z różnymi stylami, dyskursami; frenetyczna kreatywność "stawania się", a nie "bycia", nie dająca się sprowadzić do żadnej kategorii czy układu społecznego. Deleuze i Guattari ustawiaja taka siłę, określając ją "nomadyczną maszyną wojenna", w opozycji do tego, co nazywane i identyfikowane jest z Państwem, które z definicji musi "wiązać każdy rodzaj nomadyzmu z określonymi strukturami, pilnować, żeby ta kreatywność nie przekroczyła określonych granic baqdź określonych kategorii tożsamościowych"[31]. 
Problemem zatem nie byłby tylko system prawny, polityka reprezentacji, ale również sama współczesna struktura państwowa, co sugeruje (post)anarchistyczną krytykę systemu. Jeżeli jednak stwierdzimy, że w obecnej "historycznej teraźniejszości" anarchistyczne zniesienie państwa wydaje się nieprawdopodobne, to trzeba by było sobie wyobrazić państwo, które nie sankcjonuje i nie uprzywilejowuje żadnych związków, relacji, nie tworzy norm tożsamościowych lub seksualnych; w którym wszyscy obywatele i obywatelki płacą podatki, korzystaja z ochrony policyjnej, na równi uczestniczą w strukturach państwowych. Państwo (utopię?), w którym niepotrzebna byłaby polityka reprezentacji czy praktyki emancypacyjne. Państwo musiałoby przede wszystkim wypaść z roli "właściciela" i "dyktatora" definicji "poprawnych", "pożytecznych", "właściwych" instytucji i konstruktów społeczno-kulturowych, stając się odpowiedzialne wyłącznie za ochranianie wszelkich relacji i związków międzyludzkich, dobrowolnie inicjowanych przez jednostki i utrzymywanych za obopólną, bądź "wielopólna", zgodą. Relacji i związków, z których jednostki czerpią różnie rozumiane przyjemność i szczęście, dzięki którym i w których maja możliwość samorealizacji i rozwoju. Ze strukturą państwa wiążą się jednak kwestie regulacji i kontroli państwowości, które mogłyby stanowić problem dla filozofii antyreprezentacjonizmu. Kwestie: kto miałby władzę w takim państwie; z jakiego mandatu; kto kontrolowałby policję czy służby porządkowe. Można oczywiście uciec od "oświeceniowej" wizji państwa w kierunku decentralistycznego anarchistycznego federalizmu, który w tej materii miałby do zaproponowania być może bardziej atrakcyjne perspektywy.

Filozoficzna krytyka poststrukturalistyczna (m.in. Foucault, Lyotard, Deleuze i Guattari) nawołuje do celebracji różnorodności, odmienności, do eksperymentowania z różnymi stylami życia, do "otwarcia jednostki (czy to osoby, grupy czy praktyki) na nowe praktyki, praktyki, które zmieniaja, podważaja lub znoszą układy sił utrzymujące stare [normatywne - przyp. aut.] praktyki przy władzy"[32]. W tym samym tonie Elizabeth Grosz, polemizując niejako z liberalnym pomysłem na "znormatywizowany", uniwersalny podmiot, nawołuje do porzucenia prób kategoryzacji przejawów ludzkiej seksualności i budowania na bazie tych kategorii, konceptów i określeń tożsamości. Postuluje "eksperymentowanie z seksualnościa", "czerpanie przyjemności z jej różnych przejawów", "eksplorowanie punktów jej zwiększonej intensywności" i takich, które nie sposób nazwać, korzystając z gotowych etykietek[33]. Może więc zamiast tak usilnie wpychać się w przyciasnawy garnitur normatywnego, opresyjnego konstruktu, należałoby właśnie domagać się takiego stanu rzeczy, w którym to jednostka decydowałaby o charakterze swojego 
życia, o tym, kim i jak chciałaby "być" w danej chwili, o formie relacji, w której akurat $w$ danym momencie chciałaby się realizować i rozwijać. Można by sobie wyobrazić taka rzeczywistość, w której jednostki nie sa skazane na przymusowe trwanie w relacjach czy instytucjach etycznych, przypisanych im przez kulture i monitorowanych przez społeczeństwo i cała machina prawno-polityczną państwa; w której jednostki nie rodzą się do już z góry dyskursywnie wytworzonych, gotowych tożsamości, które następnie muszą odgrywać według scenariusza-klucza. Chodziłoby tutaj o pozbycie się tego pesymistycznego determinizmu etykietek tożsamościowych. O taką rzeczywistość, w której to jednostka - jak to sobie wyobraża Grosz - jest w nieustannym ruchu "tożsamościowym", jest już zawsze tożsamością-w-stawaniu-się. Dlatego tak bardzo ważne jest wprowadzanie i utrzymywanie licznych, różnorodnych pomysłów "na życie" i praktyk seksualnych, z którymi jednostki sa w stanie eksperymentować, pogłębiając swoje doświadczenie emocjonalno-społeczne, i w rezultacie rozwijać swoja seksualność. Taka różnorodność doświadczeń oraz akceptacja społeczna dla równości tych różnorodnych doświadczeń pozwoliłaby jednostce na w miarę swobodny wybór kierunku, w którym chciałaby się rozwijać w danym momencie.

\section{Tymczasem polityka tożsamościowa dyskryminowanych,}

zamiast dążyć do zniesienia całej tej dyskryminującej, heteronormatywnej machiny systemowej, podszytej etyka judeochrześcijańska, i stanowczo domagać się od państwa zrzeczenia się prawa do hierarchizacji i wartościowania praktyk tożsamościowych i pomysłów na życie, godzi się na opresjogenny, jednowymiarowy status quo systemu społeczno-kulturowego, podszyty dodatkowo (meta)narracją "rozrodczego futuryzmu", i pragnie się do niego zaadaptować. Przycinanie bogatej kultury emocjonalno-seksualnej nieheteroseksualnych opcji do monogamicznych, normatywnych, miłych i znajomych dla oka "heteroseksualisty" ram odbywa się pod hasłem odmiany społecznej, reformy kulturowej. Dochodzi w sumie do paradoksalnej sytuacji - spod jarzma heteronormatywu wyswobadza się homonormatyw [34], będący już z definicji i przez ontologię swej tożsamości dyskryminującym i opresyjnym. Bo oto tylko "gej" i "lesbijka" odpowiedniej "kompozycji tożsamościowej" będą w stanie zawrzeć małżeństwo, nazwane z przyczyn prawno-społecznych zwiazkiem partnerskim. Znowu ta instytucja będzie dostępna tylko pewnym kategoriom tożsamościowym, kategoriom, które będą musiały się dostosować, znormalizować, ujednolicić, jeśli będą chciały w niej uczestniczyć. A przez swą "ekskluzywność" i "wyjątkowość", jak również strukturę (strukturę monogamiczna, warunkowaną etyką judeochrześcijańska), w dalszym ciagu będzie deprecjonowała różne inne konfiguracje, 
relacje, układy, związki, ustawiając je, systemowo baqdź dyskursywnie, na przeciwstawnym biegunie, czyli - w przypadku polskiej rzeczywistości - czyniąc gorszymi (w sensie moralnym, etycznym, ekonomiczno-społecznym, etc.). "Gejowskie" i "lesbijskie" normatywy walczą zatem o prawo do "pełnoprawnego" uczestnictwa w monogamicznej instytucji, wypracowanej przez system "rozrodczego futuryzmu", w którym zdolność jednostki do reprodukcji i jej wartość sa ze sobą nierozerwalnie złączone. Natomiast odmienność seksualna stanowi w tymże dyskursie przecież "błąd produkcyjny", "usterkę", "produkt uboczny", jawi się jako "zmarnowane bycie / życie".

Podsumowując: polityka tożsamościowa takich organizacji gejowsko-lesbijskich, jak Kampania Przeciw Homofobii, Fundacja Równości, gaylife.pl, homofilnych ruchów lewicowych wycelowana jest w emancypacje "gejów" i "lesbijek", w rozszerzenie i wzbogacenie sfery społeczno-kulturowej o homoseksualny podmiot. Niby sa to działania "wyzwoleńcze" odbywające się pod tęczowym szyldem różnorodności i prawa do bycia soba, do życia w zgodzie z własnymi przekonaniami, emocjami iodczuciami, ale jednocześnie za pomoca praktyk normalizacyjnych, adaptacyjnych, przycina się Inność do heteronormatywnych, konserwatywnych, i w miarę strawnych dla katolicyzmu, wymiarów, produkuje się dyskursywnie konstrukty tożsamościowe "normalnej lesbijki" i "normalnego geja". A dlaczego prawa do bycia sobą i do społecznego, kulturalnego i prawnego uznania tego "prawa do bycia soba" nie może mieć osoba interseksualna, transseksualna, transgenderowa, trójkaty, czworokaty, inne konfiguracje, niesklasyfikowane jeszcze opcje seksualne, opcje seksualne, które nie chcą być sklasyfikowane, opcje seksualne, które wymykają się wszelkim definicjom, itp.? Watpliwe jest bardzo to, czy można mówić o prawdziwej różnorodności w przypadku, kiedy owa różnorodność to heteronormatyw izheteronormatywizowany homonormatyw (ko?)egzystujace w systemie społeczno-kulturowym motywowanym filozofia "rozrodczego futuryzmu" i judeochrześcijańską etyką.

\section{BIBLIOGRAFIA:}

- Biedroń R., Tęczowy elementarz, czyli (prawie) wszystko, co chcielibyście wiedzieć ogejach ilesbijkach, Wydawnictwo Adpublik, Warszawa 2007.

- Boswell J., Chrześcijaństwo, tolerancja społeczna ihomoseksualność: geje ilesbijki w Europie Zachodniej od początku ery chrześcijańskiej do XIV wieku, tł. Jerzy Krzyszpień, NOMOS, Kraków 2006.

- Browning F., A Queer Geography. Journeys Toward a Sexual Self, The Noonday Press, New York 1996/1998. 
- Butler J., Uwikłani w płeć. Feminizm i polityka tożsamości, tł. K. Krasuska, Wydawnictwo Krytyki Politycznej, Warszawa 2008.

- D'Emilio J., Capitalism and Gay Identity, w: The Columbia Reader on Lesbians and Gay Men in Media, Society, and Politics, pod red. L. Gross i J. D. Woods, s. 48-55, Columbia University Press, New York 1999.

- Deleuze G., Felix Guattari, Anti-Oedipus. Capitalism and schizophrenia, University of Minnesota Press, Minneapolis $1983 / 1996$.

- Edelman L., No Future. Queer Theory and the Death Drive, Duke University Press, Durham - London 2004.

- Fuss D., Inside/Out, w:, Inside/Out. Lesbian Theories, Gay Theories, pod red. D. Fuss, s. 1-10, Routledge, New York - London 1991.

- Grosz E., Experimental Desire: Rethinking Queer Subjectivity, w: Supposing The Subject, pod red. J. Copjec, s.133-157, Verso, London 1994/1996.

- Jagose A., Queer Theory. An introduction, Melbourne University Press, Washington Square - New York 1996 /1998.

- Kristeva J., Potęga obrzydzenia. Esej o wstręcie, tł. M. Falski, Wydawnictwo Uniwersytetu Jagiellońskiego, Kraków 2007.

- May T., The Political Philosophy of Poststructuralist Anarchism, The Pennsylvania State University Press, Pennsylvania 1994.

- Mizielińska J. Płeć, ciało, seksualność. Od feminizmu do teorii queer, Universitas, Kraków 2006.

- Warner M., The Trouble with Normal. Sex, Politics, and the Ethics of Queer Life, Harvard University Press, Cambridge Massachusetts 1999/2001.

\section{Źródła internetowe:}

- Kulpa R., To miał być tekst o teorii queer (2005) (

)

- Leszkowicz P., Sztuka a seksualna przebudowa polskiej przestrzeni publicznej. Igor Mitoraj i Niech nas zobaczą (2005) . ( http://www.obieg.pl/text/pl sas.php )

- Strona akcji "Niech Nas Zobacza" Kampanii Przeciw Homofobii. Pobrane 13 listopada 2006. http://niechnaszobacza.queers.pl .

[1] Poprzez wzięcie wyrażeń "gej" i "lesbijka" w cudzysłów sygnalizuję, że rozpatruje je jako tożsamościowe konstrukty kulturowo-społeczne.

[2] Niezgodność gramatyczna rzeczownika "odmieniec" oraz określających go przymiotników "normalna" i "oswojona" jest zamierzona. 
[3] J. D`Emilio, "Capitalism and Gay Identity", w: The Columbia Reader on Lesbians and Gay Men in Media, Society, and Politics , pod red. L. Grossa i J. D. Woodsa, Columbia University Press, New York, s. 49. Tłumaczenie własne - R.M.

[4] Ibidem, s. 49. Tłumaczenie własne - R.M.

[5] Ibidem, s. 49.

[6] J. Boswell, Chrześcijaństwo, tolerancja społeczna i homoseksualność: geje i lesbijki w Europie Zachodniej od początku ery chrześcijańskiej do XIV wieku, tł. Jerzy Krzyszpień, NOMOS, Kraków 2006.

[7] D. Fuss, "Inside/Out", w: Inside/Out. Lesbian Theories, Gay Theories, pod red. D. Fuss, Routledge, New York 1991, s. 1-10.

[8] J. Mizielińska, "Poza kategoriami... Kilka uwag na temat teorii queer", w Idem: Płeć, ciało, seksualność. Od feminizmu do teorii queer, Universitas, Kraków 2006, s. 116.

[9] Ibidem, s. 115.

[10] A. Jagose, Queer theory. An introduction, New York University
Press, New York 1996, s. 97. Tłumaczenie własne.

[11] F. Browning, A queer geography. Journeys toward a sexual self , The Noonday Press. Farrar, Straus and Giroux, New York 1998, s. 21. Tłumaczenie własne - R.M. "Mainstream" - tutaj jako konwencjonalne rozumienie tożsamości biseksualnej, homoseksualnej, heteroseksualnej.

[12] Ibidem, s. 21. Tłumaczenie własne - R.M.

[13] J. Mizielińska, op. cit., s. 116.

[14] F. Browning, op. cit., s. 23.

[15] Strona kampanii "Niech Nas Zobacza": http://niechnaszobacza.queers.pl/

[16] P. Leszkowicz, "Sztuka a seksualna przebudowa polskiej przestrzeni publicznej. Igor Mitoraj i Niech Nas Zobacza", na: http://www.obieg.pl/text/pl_sas.php, Obieg 2005.

[17] J. Kulpa, "To miał być tekst o teorii queer", na:

Recykling Idei 2005. 
[18] "Abjekt", tłumaczony też jako "wy-miot" albo "pomiot", w filozofii Julii Kristevy to, najprościej rzecz biorąc, to, co musi zostać wydalone poprzez praktykę wstrętu, aby podmiot mógł się ukonstytuować. J. Kristeva, Potęga obrzydzenia. Esej o wstręcie , tł. M. Falski, Wydawnictwo Uniwersytetu Jagiellońskiego, Kraków 2007.

[19] "Nadkodowanie" Deleuze i Guattari tłumaczą w Anti-Oedipus (G. Deleuze, Felix Guattari, Anti-Oedipus. Capitalism and schizophrenia, translated from The French by Robert Hurley, Mark Seem, and Helen R. Lane, University of Minnesota Press, Minneapolis 1996) jako charakterystyczny dla każdej formy państwowości proces podciagania rozmaitych, przeciwstawnych praktyk pod pewną określona normę, zamykania ich w pewnej określonej kategorii; praktyki te zaczynają być równocześnie "rozpoznawane" i "rozumiane" jako wariacje tej normy czy kategorii (por. T. May, op. cit., s. 106). Jak pisze May, "to, co kiedyś było czymś innym, odmiennym, staje się teraz jedynie odmianą tego samego" (Ibidem, s. 106. Tłumaczenie własne). "Państwo poprzez nadkodowywanie różnych kodów społecznych (...) próbuje zapewnić ciagłość niektórych kodów, starając się jednocześnie doprowadzić do wygaszenia innych; co skutkuje zawłaszczeniem (...) pewnych praktyk oraz marginalizacja lub eliminacja innych" (lbidem, s. 107. Tłumaczenie własne - R.M.).
[20] Niezgodność gramatyczna między frazą rzeczownikowa "dysydent seksualny" a czasownikiem "musiała" zamierzona.

[21] J. Butler, Uwikłani w płeć, tł. K. Krasuska, Wydawnictwo Krytyki Politycznej, Warszawa 2008, s. 49.

[22] L. Edelman, No future. Queer theory and the death drive, Duke University Press, Durham 2004, s. 3. Tłumaczenie własne - R.M.

[23] Wśród tych stereotypów istnieje m.in. dyskurs utożsamiający "geja", prawie nigdy "lesbijkę", z predatorem seksualnym, którego życie zorganizowane jest wokół zaspokajania swego popędu seksualnego. Fantazmatyczny "gej" jawi się jako rozwiazły, podejmujący się ryzykownych zachowań seksualnych, niezdolny do stworzenia stabilnego, "produktywnego" zwiąku. Figura "lesbijki" jest praktycznie nieobecna w polskich dyskursach publicznym i społeczno-kulturowym, pojawiając się pod postacia erotycznego fantomu w fantazjach erotycznych heteroseksualnych mężczyzn. Przyczyny "niewidoczności lesbijskiej" można doszukiwać się, między innymi, w nazewnictwie związanym zhomoseksualnością używanym w dyskursie publicznym, który, operując męskoosobowym terminem "homoseksualista", ustawia kognitywne mechanizmy społeczeństwa wokół figury podmiotu męskiego. Co więcej 
w bardzo mocno patriarchalnej kulturze polskiej to właśnie "homoseksualista" płci męskiej zagraża destabilizacja statusu quo figury Patriarchy-Mężczyzny, a nie "lesbijka", która, po pierwsze jako biologiczna kobieta historycznie, kulturowo i społecznie podlega mężczyźnie; po drugie - fakt, że posiada waginę ustawia ja w świadomości społecznej jako "tożsamość kobieca", która jest z kolei konstruktem języka fallogocentrycznego; a po trzecie "lesbijka" pomniejsza swoją wartość kulturowo-społeczna wychodząc ze ściśle heteronormatywnej roli "kobiety" jako "tej, która jest obiektem pożądania mężczyzny". Negatywne stereotypy związane z "gejami" utrzymuja się w polskim dyskursie publicznym również dlatego, że bardzo często operuje się słowami "homoseksualizm" i "homoseksualista", które budzą jednoznaczne kognitywne, konceptualne skojarzenia, odnosząc się do sfery seksualnej, seksu.

[24] R. Biedroń, Tęczowy elementarz czyli (prawie) wszystko, co chcielibyście wiedzieć ogejach ilesbijkach , Wydawnictwo Adpublik, Warszawa 2007, s. 45.

[25] M. Warner, The Trouble with normal: sex, politics, and the ethics of queer lifeM/i

[26] Ibidem, s. 112. Tłumaczenie własne - R.M.
[27] Ibidem, s. 112. Tłumaczenie własne - R.M.

[28] Taka praktyka prawna miałaby pewnie wpływ na układ oraz relacje dyskursów ipraktyk społecznych wobrębie przestrzeni społecznej, rozumianej poststrukturalistycznie jako społeczna sieć praktyk, której charakter uzależniony jest od układu sit pomiędzy tymi praktykami. Zmieniłaby polaryzację w pewnych punktach opresji, doprowadziła do uformowania się nowych punktów oporu.

[29] T. May, The Political Philosophy of Poststructuralist Anarchism , The Pennsylvania State University Press, Pennsylvania 1994, s. 131. Tłumaczenie własne - R.M.

[30] Ibidem, s. 127. Tłumaczenie własne - R.M.

[31] Ibidem, s. 105. Tłumaczenie własne - R.M.

[32] Ibidem, op. cit., s. 113. Tłumaczenie własne - R.M.

[33] E. Grosz, "Experimental Desire: Rethinking Queer Subjectivity", w: Supposing The Subject, pod red. J. Copjec, Verso, London 1996, s. 152. Tłumaczenie własne - R.M. 
[34] A raczej "gej-i-lesbijka-tacy-jak-na-zdjęciach-'Niech Nas Zobacza'-normatyw".

\section{Rafał Majka}

